NASA/TM-2003-212454

\title{
NASA GRC Stirling Technology Development Overview
}

\author{
Lanny G. Thieme and Jeffrey G. Schreiber
}

Glenn Research Center, Cleveland, Ohio 
Since its founding, NASA has been dedicated to the advancement of aeronautics and space science. The NASA Scientific and Technical Information (STI) Program Office plays a key part in helping NASA maintain this important role.

The NASA STI Program Office is operated by Langley Research Center, the Lead Center for NASA's scientific and technical information. The NASA STI Program Office provides access to the NASA STI Database, the largest collection of aeronautical and space science STI in the world. The Program Office is also NASA's institutional mechanism for disseminating the results of its research and development activities. These results are published by NASA in the NASA STI Report Series, which includes the following report types:

- $\quad$ TECHNICAL PUBLICATION. Reports of completed research or a major significant phase of research that present the results of NASA programs and include extensive data or theoretical analysis. Includes compilations of significant scientific and technical data and information deemed to be of continuing reference value. NASA's counterpart of peerreviewed formal professional papers but has less stringent limitations on manuscript length and extent of graphic presentations.

- TECHNICAL MEMORANDUM. Scientific and technical findings that are preliminary or of specialized interest, e.g., quick release reports, working papers, and bibliographies that contain minimal annotation. Does not contain extensive analysis.

- CONTRACTOR REPORT. Scientific and technical findings by NASA-sponsored contractors and grantees.
- CONFERENCE PUBLICATION. Collected papers from scientific and technical conferences, symposia, seminars, or other meetings sponsored or cosponsored by NASA.

- SPECIAL PUBLICATION. Scientific, technical, or historical information from NASA programs, projects, and missions, often concerned with subjects having substantial public interest.

- TECHNICAL TRANSLATION. Englishlanguage translations of foreign scientific and technical material pertinent to NASA's mission.

Specialized services that complement the STI Program Office's diverse offerings include creating custom thesauri, building customized databases, organizing and publishing research results ... even providing videos.

For more information about the NASA STI Program Office, see the following:

- Access the NASA STI Program Home Page at http://www.sti.nasa.gov

- E-mail your question via the Internet to help@sti.nasa.gov

- Fax your question to the NASA Access Help Desk at 301-621-0134

- Telephone the NASA Access Help Desk at 301-621-0390

- Write to:

NASA Access Help Desk

NASA Center for AeroSpace Information 7121 Standard Drive

Hanover, MD 21076 
NASA/TM-2003-212454

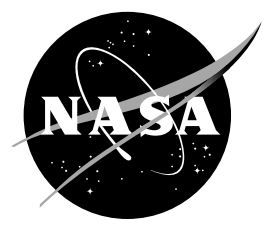

\section{NASA GRC Stirling Technology Development Overview}

Lanny G. Thieme and Jeffrey G. Schreiber

Glenn Research Center, Cleveland, Ohio

Prepared for the

Space Technology and Applications International Forum (STAIF-2003) cosponsored by the United States Department of Energy and the National Aeronautics and Space Administration Albuquerque, New Mexico, February 2-5, 2003

National Aeronautics and Space Administration

Glenn Research Center 


\section{Acknowledgments}

The work described in this paper was performed for the Office of Space Science (Code S) and the Office of Aerospace Technology (Code R) at NASA Headquarters, both of which provided funding for these efforts.

Trade names or manufacturers' names are used in this report for identification only. This usage does not constitute an official endorsement, either expressed or implied, by the National Aeronautics and Space Administration.

Available from

NASA Center for Aerospace Information 7121 Standard Drive

Hanover, MD 21076
National Technical Information Service 5285 Port Royal Road Springfield, VA 22100

Available electronically at http:/ /gltrs.grc.nasa.gov 


\title{
NASA GRC Stirling Technology Development Overview
}

\author{
Lanny G. Thieme and Jeffrey G. Schreiber \\ National Aeronautics and Space Administration \\ Glenn Research Center \\ 21000 Brookpark Road \\ Cleveland, Ohio 44135
}

\begin{abstract}
The Department of Energy, Lockheed Martin (LM), Stirling Technology Company, and NASA Glenn Research Center (GRC) are developing a high-efficiency Stirling Radioisotope Generator (SRG) for potential NASA Space Science missions. The SRG is being developed for multimission use, including providing spacecraft onboard electric power for NASA deep space missions and power for unmanned Mars rovers. NASA GRC is conducting an inhouse supporting technology project to assist in developing the Stirling convertor for space qualification and mission implementation. Preparations are underway for a thermal/vacuum system demonstration and unattended operation during endurance testing of the 55-We Technology Demonstration Convertors. Heater head life assessment efforts continue, including verification of the heater head brazing and heat treatment schedules and evaluation of any potential regenerator oxidation. Long-term magnet aging tests are continuing to characterize any possible aging in the strength or demagnetization resistance of the permanent magnets used in the linear alternator. Testing of the magnet/lamination epoxy bond for performance and lifetime characteristics is now underway. These efforts are expected to provide key inputs as the system integrator, LM, begins system development of the SRG. GRC is also developing advanced technology for Stirling convertors. Cleveland State University (CSU) is progressing toward a multi-dimensional Stirling computational fluid dynamics code, capable of modeling complete convertors. Validation efforts at both CSU and the University of Minnesota are complementing the code development. New efforts have been started this year on a lightweight convertor, advanced controllers, high-temperature materials, and an end-to-end system dynamics model. Performance and mass improvement goals have been established for second- and third-generation Stirling radioisotope power systems.
\end{abstract}

\section{INTRODUCTION}

The Department of Energy (DOE), Lockheed Martin (LM), Stirling Technology Company (STC), and NASA Glenn Research Center (GRC) are developing a high-efficiency Stirling Radioisotope Generator (SRG) for potential NASA Space Science missions. The SRG is being developed for multimission use, including providing electric power for unmanned Mars rovers and deep space missions. The SRG will provide a high-efficiency power source alternative to replace Radioisotope Thermoelectric Generators (RTG's). The SRG system efficiency of greater than $20 \%$ will reduce the required amount of radioisotope by a factor of four or more compared to RTG's. This significantly reduces radioisotope cost, radiological inventory, and system cost.

DOE has recently named LM as the System Integration Contractor. LM will develop the SRG engineering unit under contract to DOE, with contract options to develop the qualification unit and the first flight units. The SRG concept is described by Cockfield (2002). The SRG is expected to produce about $114 \mathrm{Wdc}$ at beginning-of-mission (BOM) using two opposed Stirling convertors and two General Purpose Heat Source (GPHS) modules. The system efficiency is projected to be $23 \%$, and the BOM specific power is $4.2 \mathrm{~W} / \mathrm{kg}$.

STC has previously developed the Stirling convertor under contract to DOE (Qiu, 2002) and is now providing further development as a subcontractor to LM. A total of twelve Technology Demonstration Convertors (TDC's) have been built by STC and are being tested by both STC and GRC. The TDC is now being transitioned to a flight prototype convertor. Four further TDC's are being fabricated to demonstrate any modifications for the flight prototype version and also additional quality assurance practices that STC has implemented to prepare for flight convertor fabrication. GRC is providing technical consulting for the TDC development effort under a Space Act Agreement with DOE. 
GRC is conducting an in-house technology project to assist in developing the convertor for space qualification and mission implementation. This includes independent verification testing of the TDC's, heater head life assessment, permanent magnet aging characterization, linear alternator evaluations, launch environment characterization testing, electromagnetic interference and electromagnetic compatibility (EMI/EMC) characterization and reduction, organic materials evaluations, and reliability studies. GRC has also initiated efforts to develop advanced Stirling technologies. The development of a multi-dimensional Stirling computational fluid dynamics (CFD) code, capable of modeling complete convertors, has been underway for over two years. New efforts have been started this year on a lightweight convertor, advanced controllers, high-temperature materials, and an end-to-end system dynamics model. Performance and mass improvement goals have been established for second- and third-generation Stirling radioisotope power systems. Previous project results were discussed by Thieme (2002). This paper will discuss the status and recent results for this work.

\section{TDC PERFORMANCE TESTING}

The Stirling Research Laboratory (SRL) was established at GRC to have the capability to support a wide variety of tests related to the overall performance of Stirling power convertors. An overview of the capabilities of the facility and a description of some of the tests were presented by Schreiber (2002). Tests conducted in the SRL have generally addressed three main areas: 1) performance mapping of the Stirling convertors, 2) controller development and interaction of Stirling convertors with the controllers, and 3) Independent Validation \& Verification (IV\&V) of performance. The laboratory can operate convertors as single units, or in the dynamically balanced dual-opposed configuration as shown in figure 1. The SRL data system was described in the aforementioned reference. Specialized instrumentation and modifications to the data system are used as needed to support some of the tests. Preparations have been completed for unattended operation, including modifications to the hardware and software to maintain a safe operating environment that is commensurate with attended operation. The data system is based on LabView ${ }^{\mathrm{TM}}$ software. The software was modified to control relays based on limit checking of critical parameters to provide a controlled shutdown if necessary and to archive data from that shutdown. A high-speed failsafe circuit was developed that operates in parallel to the data system. This circuit enhances safety by initiating shutdown of the convertors within the first half-cycle of operation should any of five dynamic parameters exceed their allowed operating range. The LabView $^{\mathrm{TM}}$-based data system and the failsafe circuit have been verified through tests to be able to handle any shutdown situation that may occur, including building power outage, and bring the convertors to the nonoperating ambient condition in a controlled manner.

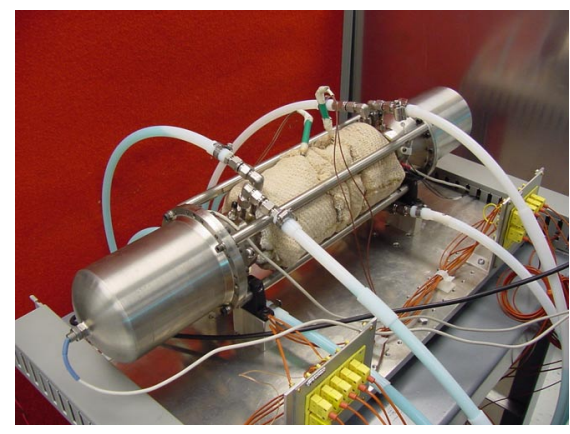

FIGURE 1. TDC's Prepared for Testing in the Dual-Opposed Configuration.

As part of the technology development effort at GRC, tests have been performed to investigate the characteristics of various controller architectures. This is important since the architecture of the controller may impact the EMI characteristics of the convertor. Initial performance tests at GRC used the zener-diode controller that was developed by STC. The zener-diode controller was found to be ideal for performance mapping of convertors in a laboratory environment; however, this controller leads to significant harmonic content in the output current from the linear alternator. A first-generation digital controller was developed at GRC that significantly reduced the harmonic content of the current. This controller also maintained the near-unity power factor of the output. Tests were performed to compare power and efficiency obtained with the two controllers, and little difference was found in the performance. While performance with the first-generation digital controller was acceptable, the controller was an assembly of three main circuit boards with numerous wiring interconnects. A second-generation digital controller with similar operating characteristics has been designed to replace the first-generation unit. The second-generation controller is more compact and built on a single printed circuit board for increased reliability. The first-generation controller was essentially a voltage-controlled resistor without feedback, and therefore output voltage would change slightly in response to the power output. The second-generation controller incorporates a feedback loop with proportional control logic and will be able to maintain constant output voltage over a wide range of power levels. The printed circuit board has been fabricated and populated with components and is presently being prepared for test. 


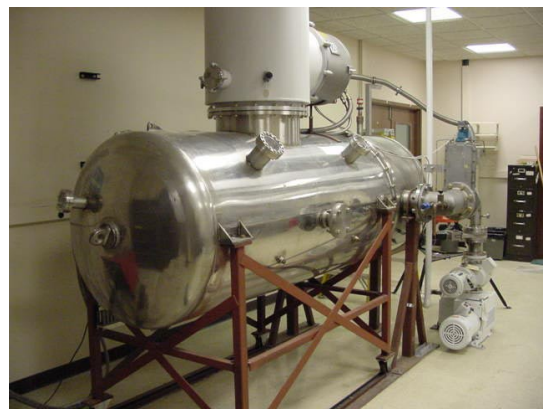

FIGURE 2. VF-67 at GRC with the CryoPump Mounted on Top of the Tank.

A thermal vacuum test has been proposed to demonstrate the operation of an opposed pair of TDC's in a relevant space environment. A test fixture has been designed to approximate operation in the SRG configuration that is being developed by LM (Cockfield, 2002). The GRC vacuum tank, known as VF-67, will be used for this test. VF-67 has liquid nitrogen cold walls and has the capacity to hold a test article that is 0.84 meters in diameter and 1.8 meters in length. VF-67, as shown in figure 2, includes a two-stage roughing train and a Leybold RPK-10000 cryogenic vacuum pump. For this test, heat will be supplied to the Stirling heater heads through a "hot shoe". The hot shoe is a thermal interface that is used to couple the heat source to the Stirling convertor heater head. In the space application, the heat source would be a single GPHS module. However, in the thermal vacuum test, the heat source will be a high-temperature ceramic electric resistance heater element. The laboratory hot shoe has the ceramic heater attached to the face of the hot shoe in an arrangement that is similar to the LM conceptual design. Heat is conducted axially along the hot shoe to the heater head, where it is then transferred radially inward to the working fluid of the cycle. Heat rejection in the space application is through radiation coupling of the radiator panels to the cold sink of deep space. In the LM design, the outer housing serves as both structure and radiator surface. For the thermal vacuum test, eight individual aluminum radiator panels have been fabricated to provide a rough approximation of the SRG housing. The panels were coated with high emissivity paint to enhance heat transfer to the cold walls of the facility. The arrangement of the radiator panels being prepared for the test is shown in figure 3. Aluminum conduction blocks will be used in this test to transfer waste heat from the Stirling cylinder to the radiator panels. This design results in increased mass and lower thermal performance compared to the flight system; however, analysis has indicated that it will be sufficient for this demonstration. This test will demonstrate the operation of the Stirling convertors in a relevant environment. It will also provide more detailed data on the performance of the thermal interfaces with the Stirling heater head.

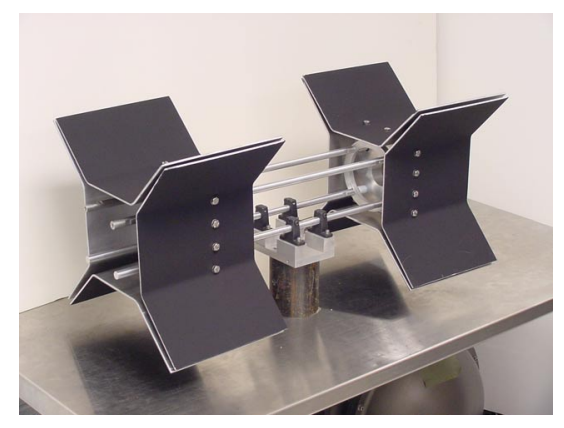

FIGURE 3. Initial Assembly of the Radiators for the Thermal Vacuum Test.

\section{HEATER HEAD LIFE ASSESSMENT AND MATERIALS STUDIES}

Heater head life is a critical element for achieving the $100,000+$ hour life of the convertor. The heater head is a thinwalled pressure vessel fabricated from Inconel 718 (IN718). GRC materials and structures personnel have developed an approach to characterize the long-term durability of the heater head using relatively short-term extrapolation methods. This approach involves both deterministic and probabilistic methods and uses IN718 material testing, an extensive long-term creep and creep-rupture database (up to 87,000 hours) taken on IN718 by the Oak Ridge National Laboratories, and heater head structural benchmark tests to calibrate and validate the analytical models. Uncertainties and variations in the IN718 material properties, the heater head geometry, and the convertor operating conditions will be considered in the probabilistic analysis. The structural benchmark tests will factor in the biaxial stress state. These will include tests of heater head shells, some of which will use increased pressure levels to accelerate the testing, and a 12-18 month test of a complete heater head at design operating conditions.

Creep testing of the IN718 material that will be used to build the convertors for the SRG engineering unit and any first flight convertors is continuing at GRC. 121,267 total hours of creep testing have been accumulated on multiple samples as of August 31,2002. Thin samples that are relevant to the heater head wall thickness are tested at different stress levels and two temperature levels, most samples at $650{ }^{\circ} \mathrm{C}$ and several at $593{ }^{\circ} \mathrm{C}$. The ORNL data is being used by GRC to factor in long-term results and measured statistical variations. The flight material being tested at GRC differs somewhat from that tested by ORNL in heat treats, grain sizes, slight variations in alloy chemistry, and especially in the thickness of the test specimens. Scaling factors accounting for the differences between the ORNL data and the GRC data will be established as the GRC database nears completion. A discussion of these various aspects of assessing IN718 for long-term creep resistance is given by Bowman (2001). 
This heater head life assessment approach and initial results for the TDC are discussed by Halford (2002). Based on these results and subsequent discussions, STC has increased the thickness of the pressure vessel wall at the hot end of the regenerator, over a relatively short span, to achieve the required lifetime. STC and GRC also worked together to verify that the heater head brazing and heat treating procedures that were developed on laboratory samples will yield the desired microstructures in the flight hardware heater heads. STC fabricated and processed two heater heads. Coupon-sized samples machined from the IN718 flight material were also included at various locations in the brazing furnace. These coupons were first examined at GRC to document their initial microstructures. After processing at STC, the heater heads and coupons were analyzed by GRC. The study showed that no grain growth had occurred during the processing and that the precipitate sizes and distributions were good; thus, the desired microstructures were achieved. Further studies evaluated the effect of re-brazes on the heater heads, in particular how much low-strength braze filler metal diffuses into the thin heater head wall.

The oxidation resistance of the stainless steel regenerators that are currently used in the TDC's has been investigated by GRC and STC. Processed and unprocessed regenerator material and regenerators tested in various convertors were studied. Oxidation effects were evaluated in both air and helium environments. Possible alternate materials with higher oxidation resistance are also being studied. A further effort is looking at the need for coatings on the displacer radiation shields to maintain a stable, low emissivity surface over the life of the convertor. The level of cleanliness of the flight convertors, including the helium fill, and any possible outgassing of organic materials are factors in minimizing any oxidation effects on these components. These cleanliness issues have been addressed in Stirling cryocoolers, where the heat transfer at the cold finger is very sensitive to any contamination. GRC has begun investigating clean and fill helium-charging procedures for the Stirling convertors on test at GRC, as well as methods to monitor any possible gas contaminants over time as endurance testing gets underway.

\section{EVALUATION OF CONVERTOR ORGANICS}

An initial review of the organic materials used in the TDC identified the bond between the magnets and the stator lamination stack as a critical area for ensuring the long-term performance of the convertor. This bond is made with $3 \mathrm{M}$ Scotch-Weld ${ }^{\mathrm{TM}} 2216 \mathrm{~B} / \mathrm{A}$ Gray epoxy. A testing protocol was first initiated to understand the relationship between the cure conditions used in the bond and the long-term durability of the junction. These cure studies will provide optimized conditions for preparation of samples for future testing. One of the epoxy cure parameters being evaluated is the effect of the temperature environment in the Stirling convertor that could affect the strength and durability of the epoxy bond. Higher temperatures, either during the initial adhesion of the magnet-stator bond or during convertor operation, can cause additional cure of the epoxy system beyond the optimized cure state, resulting in thermal degradation.

Several tests were performed to understand the effect of temperature on both the manufacturing and in-service conditions of this bond. Isothermal aging of the standard-cured epoxy, cured for seven days at room temperature as recommended by $3 \mathrm{M}$, was completed for up to 17 days at $100{ }^{\circ} \mathrm{C}$ in an air-circulated oven. Tests were also completed for up to 25 days at $100{ }^{\circ} \mathrm{C}$ in an inert environment (nitrogen) to better simulate the actual convertor operating conditions. Analyses by DMA (Dynamic Mechanical Analysis) and mDSC (modulated Differential Scanning Calorimetry) provided a better understanding of the epoxy's storage moduli, glass transition temperature (Tg), secondary transition temperatures, residual cure reaction, and the onset of thermal degradation as a function of aging time. The epoxy's storage moduli and Tg did not change as much in nitrogen as they did in air. While these short-term tests were encouraging, longer-term durability testing is planned to age bonded magnet and stator materials for up to three years in a helium environment.

The adhesion strength, stress-strain properties, and thermal-mechanical fatigue response for the magnet/lamination bonded assembly will be determined through experiments in the expected service environment. Variables to be studied will include service loading, stress levels, temperatures up to $100{ }^{\circ} \mathrm{C}$, and epoxy bond line thickness. A life prediction model will then be developed for the bonded assembly. To date, tests are underway to measure the static and dynamic stress-strain response of the epoxy alone. DMA tests were completed and measured the epoxy's storage moduli (stiffness) as a function of frequency $(0,10$, and $80 \mathrm{hz}$ ), amplitude/strain range up to a strain level of $26 \%$, loading mode (bending by single cantilever and tension), temperature $\left(35^{\circ} \mathrm{C}\right.$ and $\left.100{ }^{\circ} \mathrm{C}\right)$, and cure conditions. These tests will help determine the test conditions and procedures for the testing on the bonded assemblies. 
Alternate methods for fabricating laminations into stacks for the TDC linear alternator are also being evaluated with an overall goal of improving quality control. The following aspects are being addressed: 1) method of providing electrical insulation on the laminations; 2) measuring electrical insulation properties; 3) method of fabricating the laminations into a cohesive stack; and 4) testing of a fabricated stack for core losses (hysteresis and eddy current). Three lamination stacks are being purchased from Thomson Lamination Co. These stacks will be bonded with an epoxy applied over the entire lamination surface and will be tested for core losses to compare to test results for standard TDC lamination stacks. A set of loose laminations has also been ordered without the standard oxidation coating to allow possible core loss testing of an un-bonded, non-oxidized lamination stack.

\section{OTHER TASKS}

Neodymium-iron-boron $(\mathrm{NdFeB})$ permanent magnets are used in the TDC linear alternators. Long-term magnet aging tests are being run on $\mathrm{NdFeB}$ magnet samples to quantify any potential magnet degradation with time and temperature. Such degradation, if any, could affect both the remnant magnetization and the demagnetization resistance. The aging tests have recently reached the primary test goal of 12,000 hours at $120{ }^{\circ} \mathrm{C}$ and with a DC demagnetizing field of $6 \mathrm{kOe}$. Magnet samples are removed periodically, characterized, and compared to their baseline characterizations completed before the start of testing to determine the rate of aging. Testing is now expected to continue to obtain additional test hours and to possibly test additional magnet types. Short-term aging tests results are discussed by Niedra (2001).

The three-dimensional (3-D) magnetostatic analytical technique developed at GRC (Geng, 2001) for the linear alternator (using Ansoft's Maxwell software) was integrated with a SPICE controller model. SPICE is the circuit simulator software used with Maxwell. One use of the coupled alternator/controller model is to generate B-field maps in the vicinity of the linear alternator to assist in developing solutions to ensure that EMI does not affect any surrounding spacecraft experiments. The integrated model was used to predict alternator terminal voltage and current. The predictions agreed fairly well with the experimental data.

Probabilistic analysis has been used to evaluate life of the heater head (Halford, 2002). The use of probabilistic techniques to evaluate life and reliability for the complete Stirling convertor is presently being studied. The goal is to extend this analysis to include all parts of the generator, including the structure, thermal transport, Stirling convertor, controller, and the radiator (Shah, 2003). This type of analysis provides insight into the value of the factors-of-safety (FOS) and the margins that exist in the design by converting FOS and margin into probability to achieve mission requirements. This analysis should also indicate which specific areas should be addressed to enhance the reliability.

Launch environment and structural dynamics have been a key area of study at GRC. Past tests have included evaluations of the characteristics of Stirling convertor components and subassemblies (Suarez, 2002) and more highly integrated systems (Goodnight, 2002). Plans are currently being made for future tests that will support the transition to flight.

\section{STIRLING ADVANCED TECHNOLOGY DEVELOPMENT}

GRC has also started a project to develop advanced technology for Stirling convertors. The overall objective is to develop a high efficiency, low mass Stirling convertor for use with a radioisotope, reactor, or solar concentrator heat source. The current efforts are focused on improvements for the SRG. Figure 4 shows performance and mass improvement goals for second- and third-generation Stirling radioisotope power systems. The first-generation system is the SRG currently being developed by LM. Reducing mass is the primary focus for the second-generation system, while the third-generation improvements primarily aim at improving efficiency. Mass improvements are based on using a lightweight Stirling convertor that significantly reduces the convertor mass and an advanced controller using power electronics. The goal of improving the high SRG efficiency to even greater values, 30-35\%, will be pursued by increasing both the Carnot efficiency and the percentage of Carnot efficiency that is achievable. Both advanced superalloys and refractories are being evaluated as high-temperature materials to increase the convertor temperature ratio and thus the Carnot efficiency. Achieving the higher percentage of Carnot efficiency is expected from convertor efficiency improvements based on multi-dimensional CFD analysis. The goal is to improve the percentage of Carnot efficiency achieved from its present $45 \%$ to $55-60 \%$. 


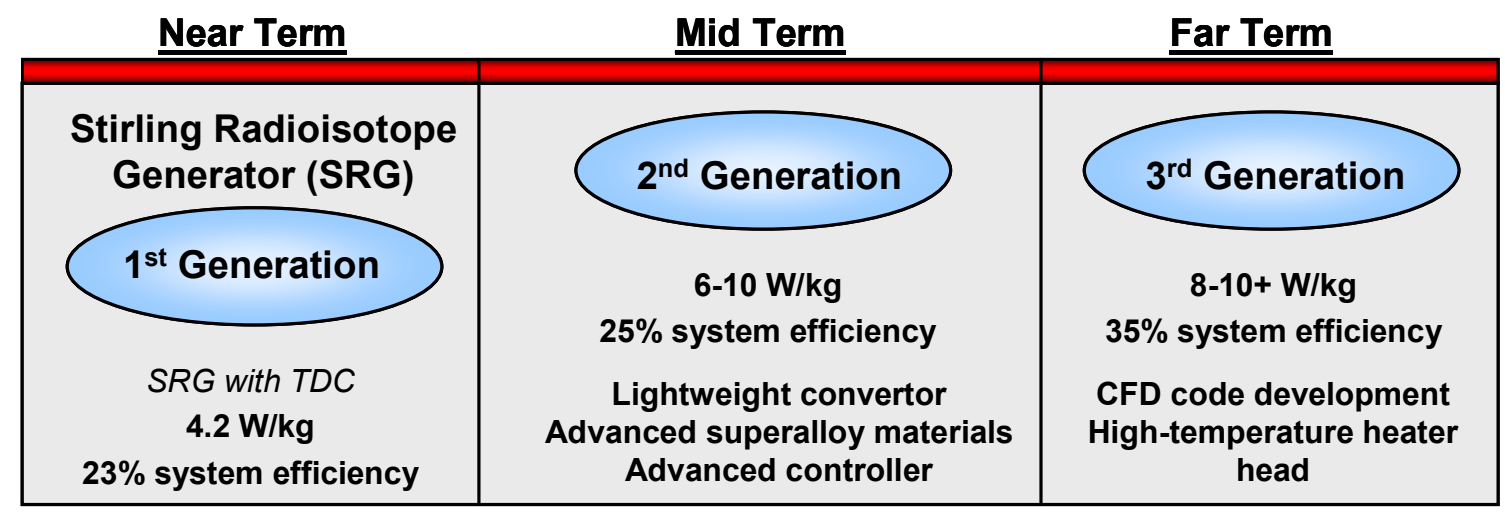

FIGURE 4. Stirling Advanced Technology Development Goals.

\section{Multi-Dimensional CFD Performance Code}

Under grant to GRC, Cleveland State University (CSU) is developing a multi-dimensional Stirling computational fluid dynamics (CFD) code to significantly improve Stirling loss predictions and assist in identifying convertor areas for further improvements. The University of Minnesota (UMN) and Gedeon Associates are teamed with CSU for this effort. The current status of this code development is given by Tew (2003). Key existing one-dimensional Stirling performance and design codes agree reasonably well with each other in terms of overall performance but can differ significantly in the magnitude of specific internal losses. Also, one-dimensional codes do not rigorously model manifolds and area changes between heat exchangers and expansion/compression spaces in the convertor. It is expected that this CFD code should give a significant improvement in the understanding of these losses and convertor design areas and, thus, help lead to further performance improvements. CSU is also leading the same team (including GRC) in a research grant on regenerators for DOE-Golden; this effort is aiding the development of the regenerator model for the multi-dimensional CFD code. This regenerator work is discussed by Ibrahim (2002a).

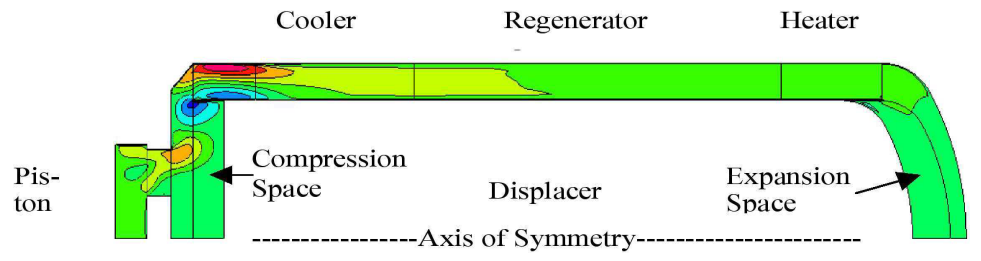

The commercial code, CFD-ACE, developed by CFD Research Corporation has been chosen for the CFD code development. A 2-D model of a Stirling convertor is now operational and is being further upgraded to include pressure vessel walls and models of the appendix gap and

FIGURE 5. Sample Velocity Contours from the 2-D CFD Code (heat exchanger details not included in this early model). seal regions. Some approximations to actual 3-D geometries, including those for the heater and cooler heat exchangers, were necessary for the 2-D axisymmetric model. This initial model uses a porous media module, included with the CFDACE code, for simulating the regenerator matrix. Work on 3-D models has also been started. One key issue is the amount of processing time needed to run a complete 3-D model of a convertor. The use of parallel clusters to significantly increase the processing speed is being investigated.

A significant amount of the effort underway is aimed at validating the Stirling CFD code. This will be done by comparison to existing test rig data, new test rig data generated as part of this project, other codes, exact solutions, and convertor test data, as appropriate. Testing is now underway with a "90-degree turn" test section at the UMN, using an existing test rig that has been modified for these tests. Flow visualization techniques with helium bubbles and a hot-wire anemometer to measure velocity are being used. These tests are described by Adolfson (2002). CSU modeled the UMN test rig for comparing test data to the CFD code; code and test results are compared by Ibrahim (2002b). Good general agreement was found with the UMN flow visualization results in first comparisons. A "180-degree turn" test section that better simulates the flow situation in a Stirling convertor is now under design; heat transfer will also be measured with this test section. CSU is also now modifying an existing test rig to provide further code validation data. GRC is making comparisons to existing gas spring and piston/cylinder/heat exchanger test rig data that were taken at the Massachusetts Institute of Technology. 


\section{High-Temperature Materials}

The TDC maximum hot-end temperature is $65^{\circ} \mathrm{C}$, with a design lifetime of $100,000+$ hours. The heater head is fabricated from the nickel-base superalloy IN718. Higher-strength superalloys are being evaluated that could allow the convertor hot-end operating temperature to be increased by several hundred degrees. A large number of nickelbase superalloys have been evaluated and screened, based primarily on creep strength and joining ability. Joining is a critical material property since the final hermetic seal on the flight prototype convertors for the SRG is expected to be done by welding. Since superalloys are typically difficult to weld (IN718 is the most easily welded nickel-base superalloy), it is this property, more so than creep strength, which limits the choice of applicable heater head materials. A down-select has been made to a small number of superalloy materials that can be welded and are also significantly stronger than IN718. If acceptable welds can be achieved, these materials could allow the convertor hot-end temperature to be operated at $750{ }^{\circ} \mathrm{C}$ or somewhat greater. Existing long-term creep data for up to about 30,000 hours have been identified for several of these superalloys. Such long-term data is relatively rare, but highly desirable, for predicting lives of $100,000+$ hours.

Since welding of superalloys presents a significant technical challenge, alternate joining techniques are under consideration. Elimination of the requirement for weldability would allow the use of even stronger superalloys that could increase the convertor hot-end temperature to as high as $870^{\circ} \mathrm{C}$. Other joining methods, such as brazing, do not present the same problems as welding since the base metal is not melted during the joining operation. Conventional furnace brazing is not an option for the final hermetic seal because the cold-end parts of the convertor cannot tolerate these higher temperatures. However, localized brazing technologies, such as torch brazing, may allow a brazed hermetic seal to be achieved without any cracking that often occurs when superalloys are welded. These alternate joining technologies will be investigated further to determine their applicability to the specific application and part geometry. Selected superalloy materials, both weldable and stronger but non-weldable, will then be taken into hardware studies, where the creep and joining properties will be evaluated.

A trade study of refractory materials is also being done with a goal of increasing the Stirling convertor hot-end temperature to as high as $1025-1125^{\circ} \mathrm{C}$. An advanced $1125^{\circ} \mathrm{C}$ heater head would not only substantially increase SRG efficiency but could possibly allow use of a combined Stirling convertor/cooler for an extended-duration surface mission on Venus. Refractory material candidates have been narrowed to several promising alloys based on their published properties. Creep, joining, and environmental compatibility issues need to be studied to fully determine their applicability. One prime issue with the refractories is that they typically have a much smaller database of test information than the superalloys, thus, making long-term life predictions more uncertain. The maximum allowable convertor hot-end temperature based on the temperature limits of the radioisotope heat source also needs to be better identified.

\section{Other Advanced Technology Tasks}

Further tasks over the past year began development of a system dynamic model, completed a conceptual design of a lightweight Stirling convertor, and began evaluations of linear alternators and advanced controllers. The end-to-end system dynamic model includes the Stirling engine thermodynamics, linear alternator, controller, and load. Various codes have been investigated for this use, including VisSim, MATLAB Simulink, and Ansoft Simplorer. The linear alternator model has been compared to the GRC 3-D model. Comparisons to TDC data have also been started. Sunpower, Inc. completed the lightweight Stirling convertor design; the results show a significantly decreased convertor mass compared to that for the first-generation SRG (Wood, 2003). System analyses performed at GRC indicate that a generator specific power of about $8 \mathrm{~W} / \mathrm{kg}$ is achievable with this technology. A controller concept has been identified, and design is now underway. The controller will use power electronics in a pulse-widthmodulated architecture. The benefits of eliminating tuning capacitors are being evaluated as part of the design process. A linear alternator test rig built by Sunpower for GRC has been installed, and first checkout tests completed.

\section{CONCLUDING REMARKS}

Key efforts in the Stirling technology development project at NASA GRC continue in the areas of performance validation; material studies; and life assessments of the heater head, $\mathrm{NdFeB}$ permanent magnets, and organic materials. These and other test characterizations and analytical studies are expected to continue to provide critical 
support to the overall SRG project as LM now begins the actual system hardware development. The development of the multi-dimensional Stirling CFD performance code is making good progress, and further advanced technology tasks are expected to next move into hardware testing. These include high-temperature materials, a lightweight Stirling convertor, and a controller based on power electronics.

\section{REFERENCES}

Adolfson, D.A., Simon, T.W., Ibrahim, M.B., and Gedeon, D., "Measurements in Oscillatory Flows with Separation in Support of Stirling Engine Model Development," Proceedings of the $37^{\text {th }}$ Intersociety Energy Conversion Engineering Conference, Washington, D.C., IECEC 2002 Paper No. 20142, 2002.

Bowman, R.R., "Long-Term Creep Assessment of a Thin-Walled Inconel 718 Stirling Power-Convertor Heater Head," Proceedings of the 36th Intersociety Energy Conversion Engineering Conference, Savannah, GA, IECEC2001-CT-33, 2001.

Cockfield, R.D. and Chan, T.S., "Stirling Radioisotope Generator for Mars Surface and Deep Space Missions," Proceedings of the 37th Intersociety Energy Conversion Engineering Conference, Washington, D.C., IECEC 2002 Paper No. $20188,2002$.

Geng, S.M., Schwarze, G.E., Niedra, J.M., and Regan, T.F., “A 3-D Magnetic Analysis of a Stirling Convertor Linear Alternator Under Load," Proceedings of the 36th Intersociety Energy Conversion Engineering Conference, Savannah, GA, IECEC2001-CT-34, NASA/TM-2001-211084, 2001.

Goodnight, T.W., Suarez, V.J., Hughes, W.O., and Samorezov, S., "Effect of Structural Mount Dynamics on a Pair of Operating Stirling Convertors," in proceedings of Space Technology and Applications International Forum (STAIF 2002), edited by M. El-Genk, AIP Conference Proceedings 608, Melville, New York, 2002, pp. 918-928.

Halford, G.R., Arya, V.K., Krause, D.L., Shah, A., and Bartolotta, P.A., "Structural Analyses of Stirling Power Convertor Heater Head for Long-Term Reliability, Durability, and Performance," in proceedings of Space Technology and Applications International Forum (STAIF 2002), edited by M. El-Genk, AIP Conference Proceedings 608, Melville, New York, pp. 880887, NASA/TM-2002-211327, 2002.

Ibrahim, M.B., Zhang, Z., Wei, R., Simon, T.W., and Gedeon, D., “A 2-D CFD Model of Oscillatory Flow with Jets Impinging on a Random Wire Regenerator Matrix," Proceedings of the $37^{\text {th }}$ Intersociety Energy Conversion Engineering Conference, Washington, D.C., IECEC 2002 Paper No. 20144, 2002a.

Ibrahim, M.B., Zhang, Z., Kembhavi, S., Simon, T.W., and Gedeon, D., “A 2-D Axisymmetric CFD Model of Oscillatory Flow with Separation," Proceedings of the $37^{\text {th }}$ Intersociety Energy Conversion Engineering Conference, Washington, D.C., IECEC 2002 Paper No. 20121, 2002b.

Niedra, J.M., "Short-Term Aging of NeFeB Magnets for Stirling Linear Alternator Applications," NASA/CR—2001-210952, 2001.

Qiu, S., Augenblick, J.E., White, M.A., Peterson, A.A., Redinger, D.L., and Petersen, S.L., "Developing a Free-Piston Stirling Convertor for Advanced Radioisotope Space Power Systems," in proceedings of Space Technology and Applications International Forum (STAIF 2002), edited by M. El-Genk, AIP Conference Proceedings 608, Melville, New York, 2002, pp. 912-917.

Schreiber, J.G. and Skupinski, R.C., "Accomplishments in Free-Piston Stirling Tests at NASA GRC," in proceedings of Space Technology and Applications International Forum (STAIF 2002), edited by M. El-Genk, AIP Conference Proceedings 608 , Melville, New York, 2002, pp. 857-864.

Shah, A.R., Schreiber, J.G., Zampino, E.J., Best, T.D., "Reliability Assessment Approach for Stirling Convertors and Generators," in proceedings of Space Technology and Applications International Forum (STAIF 2003), edited by M. ElGenk, AIP Conference Proceedings 654, Melville, New York, 2003, pp. 648-655.

Suarez, V.J., Goodnight, T.W., Hughes, W.O., Samorezov, S., "Impact Testing of a Stirling Convertor's Linear Alternator," in proceedings of Space Technology and Applications International Forum (STAIF 2002), edited by M. El-Genk, AIP Conference Proceedings 608, Melville, New York, 2002, pp. 888-897.

Tew, R.C., Cairelli, J.E., Ibrahim, M.B., Simon, T.W., and Gedeon, D., "Overview of NASA Multi-Dimensional Stirling Convertor Code Development and Validation Effort," in proceedings of Space Technology and Applications International Forum (STAIF 2003), edited by M. El-Genk, AIP Conference Proceedings 654, Melville, New York, 2003, pp. 668-676. Also NASA/TM-2002-211997, December 2002.

Thieme, L.G., Schreiber, J.S., and Mason, L.S., "Stirling Technology Development at NASA GRC," in proceedings of Space Technology and Applications International Forum (STAIF 2002), edited by M. El-Genk, AIP Conference Proceedings 608 , Melville, New York, pp. 872-879, NASA/TM-2001-211315/REV1, 2002.

Wood, J.G. and Lane, N., "Advanced 35 W Free-Piston Stirling Engine for Space Power Applications," in proceedings of Space Technology and Applications International Forum (STAIF 2003), edited by M. El-Genk, AIP Conference Proceedings 654, Melville, New York, 2003, pp. 662-667. 
Public reporting burden for this collection of information is estimated to average 1 hour per response, including the time for reviewing instructions, searching existing data sources, gathering and maintaining the data needed, and completing and reviewing the collection of information. Send comments regarding this burden estimate or any other aspect of this collection of information, including suggestions for reducing this burden, to Washington Headquarters Services, Directorate for Information Operations and Reports, 1215 Jefferson Davis Highway, Suite 1204, Arlington, VA 22202-4302, and to the Office of Management and Budget, Paperwork Reduction Project (0704-0188), Washington, DC 20503.

\begin{tabular}{|l|l|l|}
\hline 1. AGENCY USE ONLY (Leave blank) & $\begin{array}{c}\text { 2. REPORT DATE } \\
\text { August } 2003\end{array}$ & $\begin{array}{r}\text { 3. REPORT TYPE AND DATES COVERED } \\
\text { Technical Memorandum }\end{array}$ \\
\hline
\end{tabular}

\section{TITLE AND SUBTITLE} 5. FUNDING NUMBERS

NASA GRC Stirling Technology Development Overview

\section{AUTHOR(S)}

Lanny G. Thieme and Jeffrey G. Schreiber

WBS-22-896-50-01

WBS-22-755-12-14

\section{PERFORMING ORGANIZATION NAME(S) AND ADDRESS(ES)}

National Aeronautics and Space Administration

John H. Glenn Research Center at Lewis Field

Cleveland, Ohio 44135-3191

8. PERFORMING ORGANIZATION REPORT NUMBER

\section{E-13976}

\section{SPONSORING/MONITORING AGENCY NAME(S) AND ADDRESS(ES)}

10. SPONSORING/MONITORING AGENCY REPORT NUMBER

National Aeronautics and Space Administration

Washington, DC 20546-0001
NASA TM-2003-212454

\section{SUPPLEMENTARY NOTES}

Prepared for the Space Technology and Applications International Forum (STAIF-2003) cosponsored by the United States Department of Energy and the National Aeronautics and Space Administration, Albuquerque, New Mexico, February 2-5, 2003. Responsible person, Lanny G. Thieme, organization code 5490, 216-433-6119.

12a. DISTRIBUTION/AVAILABILITY STATEMENT

Unclassified - Unlimited

Subject Categories: 20 and 44
Distribution: Nonstandard

Available electronically at http://gltrs.grc.nasa.gov

This publication is available from the NASA Center for AeroSpace Information, 301-621-0390.

\section{ABSTRACT (Maximum 200 words)}

The Department of Energy, Lockheed Martin (LM), Stirling Technology Company, and NASA Glenn Research Center (GRC) are developing a high-efficiency Stirling Radioisotope Generator (SRG) for potential NASA Space Science missions. The SRG is being developed for multimission use, including providing spacecraft onboard electric power for NASA deep space missions and power for unmanned Mars rovers. NASA GRC is conducting an in-house supporting technology project to assist in developing the Stirling convertor for space qualification and mission implementation. Preparations are underway for a thermal/vacuum system demonstration and unattended operation during endurance testing of the 55-We Technology Demonstration Convertors. Heater head life assessment efforts continue, including verification of the heater head brazing and heat treatment schedules and evaluation of any potential regenerator oxidation. Long-term magnet aging tests are continuing to characterize any possible aging in the strength or demagnetization resistance of the permanent magnets used in the linear alternator. Testing of the magnet/lamination epoxy bond for performance and lifetime characteristics is now underway. These efforts are expected to provide key inputs as the system integrator, LM, begins system development of the SRG. GRC is also developing advanced technology for Stirling convertors. Cleveland State University (CSU) is progressing toward a multi-dimensional Stirling computational fluid dynamics code, capable of modeling complete convertors. Validation efforts at both CSU and the University of Minnesota are complementing the code development. New efforts have been started this year on a lightweight convertor, advanced controllers, high-temperature materials, and an end-to-end system dynamics model. Performance and mass improvement goals have been established for second- and third-generation Stirling radioisotope power systems.

14. SUBJECT TERMS

Stirling engines; Nuclear electric power generation; Deep space; Mars; Roving vehicles; Life (durability); Linear alternator; Controllers; Computational fluid dynamics; Epoxy resins; Oxidation; Heat resistant alloys

\begin{tabular}{|c|c|c|}
\hline $\begin{array}{c}\text { 17. SECURITY CLASSIFICATION } \\
\text { OF REPORT } \\
\text { Unclassified }\end{array}$ & $\begin{array}{c}\text { 18. SECURITY CLASSIFICATION } \\
\text { OF THIS PAGE } \\
\text { Unclassified }\end{array}$ & $\begin{array}{c}\text { 19. SECURITY CLASSIFICATION } \\
\text { OF ABSTRACT } \\
\text { Unclassified }\end{array}$
\end{tabular}

15. NUMBER OF PAGES 14

16. PRICE CODE 20. LIMITATION OF ABSTRACT

Standard Form 298 (Rev. 2-89) 

